\title{
Mediastinal Granular Cell Tumor
}

National Cancer Institute

\section{Source}

National Cancer Institute. Mediastinal Granular Cell Tumor. NCI Thesaurus. Code C6601.

An exceptionally rare, generally benign, granular cell tumor that arises from the mediastinum. All the reported cases were located in the posterior mediastinum. 